\title{
Quality of life assessment after parathyroidectomy in symptomatic primary hyperparathyroidism using the SF-36 questionnaire
}

\author{
Bharth Mohan $^{1}$ (D), Kishore Abuji ${ }^{1}$ (D), Divya Dahiya ${ }^{1}$ (D), Cherring Tandup ${ }^{1}$ (D), Sanjay Bhadada² (D), Arunanshu Behera ${ }^{1}$ (ID) \\ ${ }^{1}$ Department of General Surgery, Post Graduate Institute of Medical Education and Research, Chandigarh, India \\ 2 Department of Endocrinology, Post Graduate Institute of Medical Education and Research, Chandigarh, India
}

\section{ABSTRACT}

Objective: Primary hyperparathyroidism (PHPT) is a systemic disease which, along with bone and stone disease, also causes several subjective symptoms which impairs the quality of life (QoL). However, NIH guidelines do not include non-specific physical and neuropsychological symptoms as an indication of parathyroidectomy. SF-36 is one of the most commonly used tools for assessing QoL; it measures both physical health (PH) and mental health $(\mathrm{MH})$.

Material and Methods: This is a prospective observational study including 50 patients of symptomatic PHPT. Patients were categorized into normocalcemia (8.5-10.4 mg/dL), mild hypercalcemia (10.5-11.9 mg/dL), moderate hypercalcemia (12-13.9 mg/dL), and severe hypercalcemia (>14 mg/dL). QoL was assessed by using SF36 survey both pre-operative and three months after parathyroidectomy.

Results: There was an overall improvement in QoL of individual groups both in $\mathrm{PH}$ and $\mathrm{MH}$ components $(\mathrm{p}<0.001)$. The improvement was more substantial for bodily pain, role physical, vitality and mental health. Although QoL was affected in patients with mild hypercalcemia, it was more affected in patients with severe hypercalcemia. The improvement in $\mathrm{MH}$ scores was dependent on the level of pre-operative calcium; however, the improvement in PH scores was independent of pre-operative calcium $(p=0.698)$.

Conclusion: This study showed improvement in all aspects of PH and MH of SF-36 after parathyroidectomy, even in normocalcemics. Despite the fact that current guidelines for the management of PHPT do not include QoL as an indication for parathyroidectomy, we propose that parathyroidectomy should be considered, if patient is fit for surgery.

Keywords: Primary hyperparathyroidism, quality of life, parathyroidectomy, SF-36

Cite this article as: Mohan B, Abuji K, Dahiya D, Tandup C, Bhadada S, Behera A. Quality of life assessment after parathyroidectomy in symptomatic primary hyperparathyroidism using the SF-36 questionnaire. Turk J Surg 2021; 37 (3): $247-252$

\section{Corresponding Author}

Divya Dahiya

E-mail: dahiyadivya30@gmail.com

Received: 10.12 .2020

Accepted: 19.04.2021

Available Online Date: 28.09.2021

o Copyright 2021 by Turkish Surgical Society Available online at www.turkjsurg.com

DOI: $10.47717 /$ turkjsurg.2021.5156

\section{INTRODUCTION}

Primary hyperparathyroidism (PHPT) is the third most common endocrine disorder and is caused by a single adenoma in $80 \%-90 \%$ of patients (1). PHPT is a systemic disease as overproduction of PTH and hypercalcemia causes an alteration in bone metabolism (53\%), nephrocalcinosis (40\%), nephrolithiasis (70\%), cardiovascular involvement (61\%) along with neuropsychiatric symptoms (37\% to 62\%) (2-5). The majority (80\%) of PHPT patients in the Western population are asymptomatic and are diagnosed on a routine biochemical investigation. However, in India, the majority of patients who are diagnosed with PHPT either have prolonged neglected bone disease or recurrent stone disease. Symptomatic patients with severe osteoporosis suffer from multiple fractures and non-healing of fracture. Additionally, patients with undiagnosed PHPT with renal stones undergo multiple endoscopic or open procedures for renal stone disease. PHPT patients also have several subjective symptoms associated with hypercalcemia like easy fatigability, back pain, weakness, memory loss, mood swings, depression, dyspepsia and constipation.

Reduced quality of life (QoL) in PHPT is not only due to cardiovascular involvement, severe osteopenia, and stone disease but also due to countless other associated subjective symptoms. Surgery offers a cure in the majority and is measured as the definitive treatment according to the consensus statement of international guidelines. However, $\mathrm{NIH}$ guidelines do not include non-specific physical and 
neuropsychological symptoms as an indication of parathyroidectomy in PHPT patients. Surgery brings improvement in bone health; however, improvement of psychological dysfunction is still a matter of debate. There are studies from the Western world where QoL was assessed and found to have significant improvement by using various tools like Pasieka's parathyroid symptoms score, Short-Form health survey (SF-36), primary hyperparathyroidism quality of life questionnaire (PHPQOLQ) and a disease-specific Quality-of-Life questionnaire.

Objective data addressing QoL of these patients from India are limited. SF-36 is one of the most commonly used tools. It is an excellent psychometric, well organized and validated health-related questionnaire which measures both physical health $(\mathrm{PH})$ and mental health $(\mathrm{MH})$, and it is also easy to administer in a short period of time where the contact time with the patient is short. Therefore, the present study aimed to evaluate QoL using the SF-36 questionnaire in patients with PHPT before and after three months of curative parathyroidectomy.

\section{MATERIAL and METHODS}

This was a prospective observational study which included 50 symptomatic PHPT patients from a tertiary care center in North India. PHPT was diagnosed by laboratory values of serum parathormone levels (PTH), serum calcium levels, and localized by Tc $99 m$ sestamibi parathyroid scintigraphy. Patients with secondary or tertiary hyperparathyroidism, age $<18$ years or patients with multiple endocrine neoplasia were excluded. All patients underwent open focused parathyroidectomy. Approval from the institutional ethical committee was obtained.

Demographic profile, biochemical, radiological, operative and histological details were recorded. Study population was categorized as normocalcemia (8.5-10.4 mg/dL), mild hypercalcemia (10.5-11.9 mg/dL), moderate hypercalcemia (12-13.9 mg/dL), and severe hypercalcemia (>14 mg/dL). SF-36 questionnaire was used to assess QoL. Patients were asked to fill in the questionnaire within one week before surgery and three months after parathyroidectomy.

Curative parathyroidectomy was defined as the patient having persistent normal serum calcium and PTH levels three months after parathyroidectomy. Patients in the normocalcemic group should achieve normal PTH levels and serum calcium below pre-operative levels on follow up to label them as having curative parathyroidectomy.

\section{SF-36 Questionnaire}

Short-form health survey has 36-items patient-related validated survey of QoL, which was developed by RAND Corporation, California, USA. SF-36 questionnaire consists of thirty-six questions measuring PH components (physical function, role physic, bodily pain, general health and $\mathrm{MH}$ components (vitality, social functioning, role emotion, general mental health). The response for each item was scored from 0-100, and the mean score of each domain was calculated. Lower score implied poor QoL, whereas higher score indicated the excellent QoL.

\section{Statistical Analysis}

All data were analyzed by SPSS 26 (Statistical Package for the Social Sciences, IBM). Kolmogorov Smirnov tests of normality checked normality of data. Descriptive statistics were presented as mean \pm standard deviation for normally distributed variables and median [interquartile range (IQR)] for non-normally distributed variables. Descriptive statistics using parametric comparisons (t-test) were calculated. Subgroup analysis was presented as one-way ANOVA; all tests were two-sided with a 95\% confidence interval.

\section{RESULTS}

Mean age of the study group was $40.8 \pm 13.9$ years; the majority were females $(60 \%, n=30)$. Demographic profile and presenting symptoms are shown in Table 1. The majority had single gland involvement $(96 \%, n=48)$, and only two patients had double gland disease $(4 \%, n=2)$. Parathyroid adenoma was confirmed on histopathology in all patients.

\section{Biochemical Profile}

Pre-operative mean PTH was 401 pg/dL (SD= 633.67) and serum calcium was $12.25 \mathrm{mg} / \mathrm{dL}$ (SD=1.65) which normalized in all patients after surgery (Table 2). Serum PTH levels did not correlate with the severity of hypercalcemia $(p=0.521)$.

Table 1. Demographic characteristics of patients with PHPT $(n=50)$

\begin{tabular}{|l|r|}
\hline Age (years) & $40.8 \pm 13.9$ \\
Symptoms & \\
Bone pain & $44(88 \%)$ \\
Fatigue & $39(78 \%)$ \\
Muscle pain & $38(76 \%)$ \\
Renal disease & $35(70 \%)$ \\
Depression & $22(44 \%)$ \\
Difficulty in concentration & $18(36 \%)$ \\
Memory loss & $17(34 \%)$ \\
Anxiety & $15(30 \%)$ \\
Irritation & $15(30 \%)$ \\
Sleep deprivation & $13(26 \%)$ \\
Polyuria & $12(24 \%)$ \\
Nocturia & $07(14 \%)$ \\
\hline Biochemical Parameters & \\
Serum PTH (mean) & $401 \mathrm{pg} / \mathrm{ml}$ \\
Serum Calcium (mean) & $12.25 \mathrm{mg} / \mathrm{dL}$ \\
Normocalcemia (8.5-10.4 mg/dL) & $05(10 \%)$ \\
Mild hypercalcemia (10.5-11.9 mg/dL) & $18(36 \%)$ \\
Moderate hypercalcemia (12-13.9 mg/dL) & $20(40 \%)$ \\
Severe hypercalcemia (>14 mg/dL) & $07(14 \%)$ \\
\hline
\end{tabular}


Table 2. Biochemical parameters before the operation and three months after parathyroidectomy

\begin{tabular}{|l|c|c|}
\hline & Pre-operative & Post-operative at three months \\
\hline Serum calcium $(\mathrm{mg} \%)($ mean $\pm \mathrm{SD})$ & $12.25 \pm 1.65$ & $9.3 \pm 0.85$ \\
\hline Serum PTH $(\mathrm{pg} / \mathrm{ml})($ mean \pm SD) & $401 \pm 633.67$ & $44 \pm 37.73$ \\
\hline SD: Standard deviation. & & \\
\hline
\end{tabular}

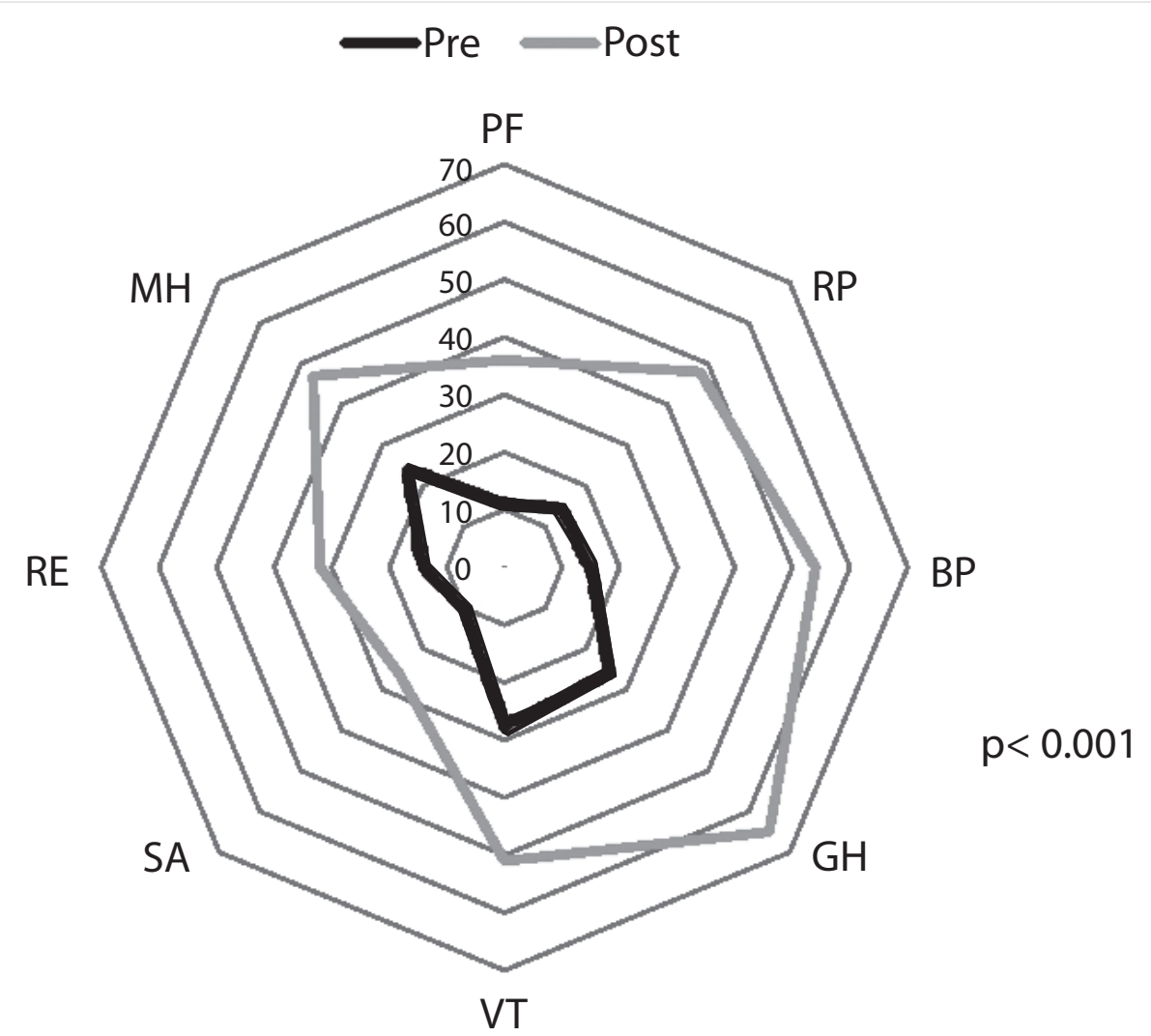

Figure 1. Comparison of mean pre-operative scores and post-operative scores in different aspects of physical health-physical function (PF), role physic (RP), bodily pain (BP), general health (GH), and mental health-vitality (VT), social activity (SA), role emotion (RE), general mental health (MH).

\section{Quality of Life Assessment}

Preoperatively, PHPT patients had significantly lower PH (49 \pm 13$)$ and $\mathrm{MH}(61 \pm 17)$, and it improved significantly after three months of curative parathyroidectomy (PH $82 \pm 6, \mathrm{MH} 81 \pm 9, \mathrm{p}<0.001$ ). There was an overall improvement in QoL of individual groups both in $\mathrm{PH}$ and $\mathrm{MH}$ components (Figure 1). The improvement was more substantial for bodily pain, role physical, vitality and general mental health.

\section{Subgroup Analysis}

Improvement in all aspects of $\mathrm{PH}$ and $\mathrm{MH}$ scores was observed in patients who underwent parathyroidectomy $(p<0.01)$. Although QoL was affected in patients with mild hypercalcemia, it was more affected in patients with severe hypercalcemia with improvement in both $\mathrm{PH}$ and $\mathrm{MH}$ score after parathyroidectomy (Table 3). The im- provement in mean $\mathrm{MH}$ scores was found to be dependent on the level of pre-operative calcium levels. However, the improvement in mean PH scores was independent of pre-operative calcium levels $(p=0.698)$. Mean MH scores were compared between groups using one-way ANOVA and were found to be statistically significant ( $p=0.032$ ).

\section{DISCUSSION}

Patients with PHPT experience various systemic and neuropsychological symptoms which attribute to reduce QoL. In this study, the impact of parathyroidectomy on QoL in PHPT patients was assessed using the SF-36 questionnaire, and it was found that there was a significant improvement in QoL after parathyroidectomy even in patients who were normocalcemic. We found considerable improvement in bodily pain, role physical, vitality and mental health. 
Table 3. Comparison of QoL pre and post-operative parathyroidectomy based on serum calcium levels

\begin{tabular}{|l|c|c|c|c|}
\hline \multirow{3}{*}{ Grades of hypercalcemia } & QoL & Pre-operative & $\begin{array}{c}\text { Post-operative } \\
\text { (after three months) }\end{array}$ & $\mathbf{p}$ \\
\hline Normocalcemia & $\mathrm{PH}$ & $65 \pm 8$ & $89 \pm 9$ & 0.002 \\
\cline { 2 - 5 } & $\mathrm{MH}$ & $80 \pm 13$ & $91 \pm 7$ & 0.018 \\
\hline \multirow{2}{*}{ Mild hypercalcemia } & $\mathrm{PH}$ & $50 \pm 11$ & $80 \pm 6$ & 0.005 \\
\cline { 2 - 5 } & $\mathrm{MH}$ & $60 \pm 18$ & $81 \pm 7$ & 0.028 \\
\hline Moderate hypercalcemia & $\mathrm{PH}$ & $49 \pm 16$ & $84 \pm 7$ & 0.007 \\
\cline { 2 - 5 } & $\mathrm{MH}$ & $66 \pm 12$ & $75 \pm 8$ & 0.001 \\
\cline { 2 - 5 } & $\mathrm{PH}$ & $33 \pm 13$ & $69 \pm 9$ & 0.009 \\
\hline \multirow{2}{*}{ Severe hypercalcemia } & $\mathrm{MH}$ & $38 \pm 10$ & & \\
\hline
\end{tabular}

In a prospective multicenter study by Weber et al. where 194 patients of PHPT with elevated depression scores and suicidal ideation were included, QoL was evaluated using the SF-36 questionnaire. Pre-operative SF-36 score was significantly lower in PHPT patients as compared to 186 patients who underwent thyroidectomy. However, there was an increase in QoL after parathyroidectomy over one year (6).

In a meta-analysis, the extent of improvement of QoL in PHPT patients after parathyroidectomy was assessed by both SF-36 and Pasieka scales. They included six studies where QoL was evaluated; 238 patients were assessed by SF-36 score, and Pasieka score was used in 203 patients, and it was found that parathyroidectomy significantly improves short- and medium-term health-related QoL after parathyroidectomy (7). In a prospective cohort analysis by David et al. which included 74 patients who underwent parathyroidectomy for PHPT and QoL was assessed using SF-36 survey before surgery and one year after parathyroidectomy. Of 74 patients, 43 were asymptomatic and 29 were symptomatic. There was significant impairment in 5 of 8 domains preoperatively with significant improvement in 7 of 8 domains postoperatively in all patients. However, the improvement was significantly more apparent in symptomatic patients, but asymptomatic patients with impaired mental health and energy level preoperatively showed improvement after parathyroidectomy (8).

Roman et al., in 28 patients with PHPT, have used the Beck Depression Inventory and Spielberger State-Trait Anxiety Inventory for assessing depression and anxiety and the Rey Auditory Verbal Learning Test and Groton Maze Learning Test for evaluating the cognitive function (9). They observed that PHPT patients were associated with higher depression score and more significant problem in spatial learning; with improvement in these parameters after parathyroidectomy. However, they did not assess QoL. However, in the present study, additional information regarding improvement in QoL was shown after parathyroidec- tomy, although cognitive functions were not measured by SF 36 surgery.

In this study, improvement in $\mathrm{MH}$ scores was found to be dependent on the level of pre-operative calcium levels, whereas $\mathrm{PH}$ scores were independent. Also, normocalcemic patients had a decreased QoL, which improved significantly after parathyroidectomy. It explains that PTH had a direct effect on QoL. In a prospective multicenter study by Bannani et al. where SF-36 questionnaire was used to assess QoL, it has been found that QoL was affected similarly among normocalcemic or hypercalcemic PHPT patients in both physical and mental aspects. There was an improvement in both physical QoL and non-specific symptoms (such as fatigue, anxiety, bone pain, muscular weakness and abdominal distension) after parathyroidectomy, but the improvement was more pronounced in the hypercalcemic PHPT patients (10). Beysal et al. have shown that normocalcemic and hypercalcemic PHPT patients had a similar risk of cardiovascular risk factors, kidney stones, metabolic syndrome and low glucose tolerance, and parathyroidectomy improved these risk factors among both groups. Recent studies have also reported that about 20 per cent of normocalcemic PHPT progresses into hypercalcemic PHPT, the majority within 2-4 years of diagnosis (11).

\section{Limitations}

SF-36 does not give information about cognitive function. The sample size for this study was small.

\section{CONCLUSION}

This study showed improvement in all aspects of $\mathrm{PH}$ and $\mathrm{MH}$ of SF-36 after parathyroidectomy, even in patients with normocalcemia. Preoperatively, QoL was significantly lower concerning role physical, general health and the physical component, and improvement was more considerable for bodily pain, role physical, vitality and mental health. Even though current guidelines for the management of PHPT do not include QoL as an indi- 
cation for parathyroidectomy, we propose that parathyroidectomy should be considered for patients with PHPT even when they do not meet the current $\mathrm{NIH}$ criteria but they are fit for surgery.

Ethics Committee Approval: This study was obtained from Postgraduate Instute of Medical Education and Research, Chandigard (Date: 21.12.2018, Decision no: 002145).

Peer-review: Externally peer-reviewed.

Author Contributions: Concept - D.D.; Design - K.A.; Supervision - D.D.; Data Collection and/or Processing - B.M.; Analysis and/or Interpratation K.A.; Literature Review - K.A.; Writing Manuscript - K.A.; Critical Reviews - C.T., A.B.

Conflict of Interest: The authors have no conflicts of interest to declare.

Financial Disclosure: The authors declared that this study has received no financial support.

\section{REFERENCES}

1. Christensson T, Hellström K, Wengle B, Alveryd A, Wikland B. Prevalence of hypercalcaemia in a health screening in Stockholm. Acta Med Scand 1976; 200(1-6): 131-7. [CrossRef]

2. Madkhali T, Alhefdhi A, Chen H, Elfenbein D. Primary hyperparathyroidism. Turk J Surg/Ulus Cerrahi Derg 2016; 32(1): 58. [CrossRef]

3. Lila AR, Sarathi V, Jagtap V, Bandgar T, Menon PS, Shah NS. Renal manifestations of primary hyperparathyroidism. Indian J Endocrinol Metab 2012; 16(2): 258. [CrossRef]

4. Shah VN, Bhadada SK, Bhansali A, Behera A, Bhattacharya A, Nahar $U$, et al. Effect of gender, biochemical parameters \& parathyroid surgery on gastrointestinal manifestations of symptomatic primary hyperparathyroidism. Indian J Med Res 2014; 139(2):279. [CrossRef]
5. Yamaguchi DT, Kleeman CR. The Neuromuscular Manifestations of Primary Hyperparathyroidism in Humans. New Actions of Parathyroid Hormone: Springer 1989; 365-77. [CrossRef]

6. Weber T, Eberle J, Messelhäuser U, Schiffmann L, Nies C, Schabram $J$, et al. Parathyroidectomy, elevated depression scores, and suicidal ideation in patients with primary hyperparathyroidism: results of a prospective multicenter study. JAMA Surg 2013 Feb 1; 148(2): 109-15. [CrossRef]

7. Brito K, Edirimanne S, Eslick GD. The extent of improvement of healthrelated quality of life as assessed by the SF36 and Pasieka scales after parathyroidectomy in patients with primary hyperparathyroidism-a systematic review and meta-analysis. Int J Surg 2015 Jan 1; 13: 245-9. [CrossRef]

8. Sheldon DG, Lee FT, Neil NJ, Ryan JA. Surgical treatment of hyperparathyroidism improves health-related quality of life. Arch Surg. 2002 Sep 1; 137(9): 1022-8. [CrossRef]

9. Roman SA, Sosa JA, Mayes L, Desmond E, Boudourakis L, Lin R, et al. Parathyroidectomy improves neurocognitive deficits in patients with primary hyperparathyroidism. Surgery 2005 Dec 1; 138(6): 1121-9. [CrossRef]

10. Bannani S, Christou N, Guerin C, Hamy A, Sebag F, Mathonnet M, et al. Effect of parathyroidectomy on quality of life and non-specific symptoms in normocalcaemic primary hyperparathyroidism. Br $\mathrm{J}$ Surg 2018 Feb; 105(3): 223-9. [CrossRef]

11. Beysel S, Caliskan M, Kizilgul M, Apaydin M, Kan S, Ozbek M, et al. Parathyroidectomy improves cardiovascular risk factors in normocalcemic and hypercalcemic primary hyperparathyroidism. BMC Cardiovasc Disor 2019 Dec 1; 19(1): 106. [CrossRef] 


\section{ORIJINAL ÇALIŞMA-ÖZET}

Turk J Surg 2021; 37 (3): 247-252

\section{SF-36 anketi kullanılarak semptomatik primer hiperparatiroidide paratiroidektomi sonrası yaşam kalitesinin değerlendirmesi}

Bharth Mohan ${ }^{1}$, Kishore Abuji ${ }^{1}$, Divya Dahiya ${ }^{1}$, Cherring Tandup ${ }^{1}$, Sanjay Bhadada ${ }^{2}$, Arunanshu Behera ${ }^{1}$

${ }^{1}$ Yüksek Lisans Tıp Eğitimi ve Araştırma Enstitüsü, Genel Cerrahi Anabilim Dalı, Chandigarh, Hindistan

${ }^{2}$ Yüksek Lisans Tıp Eğitimi ve Araştırma Enstitüsü, Endokrinoloji Anabilim Dalı, Chandigarh, Hindistan

\section{ÖZET}

Giriş ve Amaç: Primer hiperparatiroidizm (PHPT), kemiklerde veya taş oluşumlarıyla gelişen hastalıklarla yaşam kalitesini (QoL) bozan ve çeşitli öznel semptomlara neden olan sistemik bir hastalıktır. Bununla birlikte, NIH kılavuzları, paratiroidektominin bir göstergesi olarak spesifik olmayan fiziksel ve nöropsikolojik semptomları içermemektedir. SF-36 ise, yaşam kalitesini değerlendirmek için en yaygın kullanılan araçlardan biridir ve hem fiziksel sağlığı $(\mathrm{PH})$ hem de zihinsel sağlığı $(\mathrm{MH})$ ölçer.

Gereç ve Yöntem: 50 semptomatik PHPT hastasını içeren prospektif bir gözlemsel çalışma yapıldı. Hastalar normokalsemi (8,5-10,4 mg/dL), hafif hiperkalsemi (10,5-11,9 mg/dL), orta derecede hiperkalsemi (12-13,9 mg/dL) ve şiddetli hiperkalsemi (> $14 \mathrm{mg} / \mathrm{dL})$ olarak kategorize edildi. QoL, SF36 anketi kullanılarak hem ameliyat öncesi hem de paratiroidektomiden üç ay sonra değerlendirildi.

Bulgular: Hem PH hem de MH bileşenlerinde bireysel grupların QoL'sinde genel bir iyileşme görüldü $(p<0,001)$. lyileşme bedensel ağrı, fiziksel rol, canlılık ve zihinsel sağlık için daha önemliydi. Hafif hiperkalsemili hastalarda yaşam kalitesi etkilenmiş olmasına rağmen, bu durum şiddetli hiperkalsemili hastalarda daha fazla saptandı. MH skorlarındaki iyileşme, ameliyat öncesi kalsiyum düzeyine bağlıyken, PH skorlarındaki düzelme ameliyat öncesi kalsiyumdan bağımsızdı $(p=0,698)$.

Sonuç: Bu çalışmanın sonuçları, normokalsemiklerde bile paratiroidektomiden sonra SF-36'nın PH ve MH'sinin tüm yönlerindeki iyileşmeyi göstermektedir. PHPT'nin tedavisinde mevcut kılavuzlar paratiroidektomi için bir endikasyon olarak QoL'yi içermese de, hastalar cerrahiye uygunsa paratiroidektominin düşünülmesini önermekteyiz.

Anahtar Kelimeler: Birincil hiperparatiroidizm, yaşam kalitesi, paratiroidektomi, SF-36

Doi: $10.47717 /$ turkjsurg.2021.5156 